\title{
Narrative Navigation: HIV and (Good) Care in Aceh, Indonesia
}

\author{
Annemarie Samuels ${ }^{1}$ if
}

\begin{abstract}
In this article, I elaborate the concept of narrative navigation to analyze the subjective and intersubjective ways in which people struggle through experiences of illness by constructing multiple, ambiguous and non-linear narratives that may continuously change, as they reposition themselves within changing circumstances. Drawing on ethnographic material on HIV care in Aceh, Indonesia, I show how subjunctivity and open-endedness are crucial narrative ways in which people living with HIV, their relatives, medical doctors and support group workers adjust to possibilities and limitations of care over time, thereby continuously negotiating what good care may be. Unfolding within a changing Indonesian healthcare system, their narrative navigations reveal caregiving to be a complex and contradictory process, thereby problematizing boundaries between good care and neglect.
\end{abstract}

Keywords Narrative navigation - Care · HIV/AIDS · Subjunctivity · Indonesia

\section{Introduction}

How do narratives shape practices of care? Anthropologists concerned with this question have shown how people create narrative interpretations of illness in and beyond clinics, and how interactions with caregivers shape patients' narratives of the future (e.g., Kleinman 1988; Good and Good 2000; Mattingly 1998, 2010; Mattingly and Garro 2000). Narratives of illness and healing are often non-linear, and containing subjunctive elements that sustain multiple possible plots (Abadía-

Annemarie Samuels

a.samuels@fsw.leidenuniv.nl

1 Institute of Cultural Anthropology and Development Sociology, Leiden University, Wassenaarseweg 52, 2333 AK Leiden, The Netherlands 
Barrero 2011; Black 2015; Garro 2003; Good and Good 1994; Mattingly 2014; Samuels 2018; Shohet 2007, 2018b). Moreover, in everyday practices of care, caregivers and patients frequently engage in what Cheryl Mattingly (2014:20) has called narrative re-envisioning: "the activity of coming to see oneself in a new way, coming to reform one's sense of possibility and reframe one's commitment."

Drawing on ethnographic research on HIV care in Indonesia, in this article I bring these insights about illness narratives in conversation with recent anthropological work on "social navigation" (Vigh 2006, 2009). Studying "narrative navigation," I suggest, illuminates the subjective and intersubjective ways in which people struggle through troubling events by constructing multiple, ambiguous and often non-linear narratives that may continuously change over time as they reposition themselves within changing circumstances. Narrative navigation may include narrative re-envisioning, but also involves shifting back and forth between multiple perspectives in a constant process of adjustment to an uncertain social environment. In this process, people may create new narrative plots of their pasts and futures. Yet, I emphasize that narrative navigation may also entail an active under-plotting of the future, leaving potential trajectories as undetermined as possible.

The concept of narrative navigation, then, offers a tool for analyzing the narrative dimensions of the ways in which individuals shape and adjust to changing social worlds over time. This process becomes particularly clear in times of trouble. Building on the vibrant scholarship on narratives, illness and care cited above, I here address specifically how focusing on narrative navigation can illuminate how the question of what is "good" care is or may be, is open to constant negotiation and change. In the next section, I elaborate this theoretical perspective on narrative navigation and care. Subsequently, I sketch the context of HIV-care in Indonesia and my research with people living with HIV, support group staff members, medical doctors and family members in the province of Aceh, before turning to two stories that reveal the work of narrative navigation.

\section{Narrative Navigation and Care}

In his theorization of the concept of "social navigation," Henrik Vigh (2009:425) explains how navigation, originating in seafaring, "designates motion within motion." Noting that social navigation is still often equated with a form of mapusing within rather stable "gps-landscapes," Vigh (2009:427) argues that it is more useful to look at the ways in which people move within "social environments" that are themselves continuously changing. This does not mean, Vigh cautions, that everything is always in flux-some social contexts provide more stability than others. Yet, in many of the places and situations in which anthropologists work, it is more helpful to analyze social environments as changing than to presume the relative stability that the landscape metaphor invokes. Importantly, Vigh allows for a dense temporality of social navigation, emphasizing that in acting in the present, we anticipate what may come, continuously adjusting these future scenarios as circumstances change. Narrative is important here, because "social navigation is to 
plot, to actualize plotted trajectories and to relate one's plots and actions to the constant possibility of change" (Vigh 2009:426).

The work of emplotment involved in social navigation resembles what Cheryl Mattingly (2010) has analyzed through a "narrative phenomenology of practice." In her dramaturgical approach, Mattingly (2010:43) starts from the position that "as everyday actors, we locate ourselves in unfolding stories that inform our commitments about what is possible and desirable, our narrative anticipations and judgments about how things should and will unfold, and an understanding of the motives and actions of our interlocutors." Experience, Mattingly notes elsewhere (2014), may denote a kind of passage or journey. It is a perilous and uncertain journey in which we find ourselves "to be living within possible narrative plotlines that stretch backward and forward in time" (Mattingly 2014:73). Similarly, for Michael Jackson (2013[2002]), storytelling is itself a way of "journeying." Narrative, from these perspectives, crucially shapes our experience as a journey, unfolding over time and adjusting to the possibilities that open up as well as the directions that are foreclosed.

Perhaps not all social navigation is narrative (one may think, for instance, of socially embodied adjustment to change), but clearly narrative offers people a crucial way of moving through troubled waters. Looking specifically at "narrative navigation," therefore, helps us focus on the ways in which people use, create, and modify narratives to shape their lives within ever-changing circumstances. To put it differently, narrative offers one crucial device of social navigation, and looking closely at narrative practices may help illuminate how people move within unstable social worlds.

The concept of navigation brings to narrative studies an analytical focus on the ways in which people move within social forces that are themselves also moving. Yet while the narrative ways in which they do so often involve plotting diverse trajectories and adjusting such plots, I suggest that the concept of narrative navigation also enables us to see how people often do not create clear plots, but retain ambivalence, doubt, and open-endedness. In other words, if storytelling, as Jackson (2013[2002]) points out, helps us to regain a sense of control over uncontrollable circumstances, it does not only do so by offering coherent paths, but also by allowing for the possibility to not choose a direction. Differing from ship navigation, where one needs to steer a course to reach the destination, in the narrative navigation of social life, people may suspend opting for one direction or another, leaving trajectories open. ${ }^{1}$ While the narratives we construct to navigate troubling circumstances may be linear, offering one straightforward trajectory, they are more often non-linear, ambiguous and open-ended (cf. Garro 2003; Samuels 2018; Shohet 2017).

In this article, I present two ethnographic vignettes to illuminate how people living with HIV and their caregivers narratively navigate care. Many of them forcefully experienced the instability of their lifeworlds, through an HIV-diagnosis and uncertainty about the virus destabilizing the body, frustrations and limits of

\footnotetext{
1 The analysis of narrative navigation as a non-linear and open-ended intersubjective practice thereby differs considerably from Edwin Hutchins' (1995) anthropological study of actual ship navigation in the framework of a cultural cognitive system.
} 
caregiving, and the possibilities and impossibilities of the Indonesian healthcare system. For all of them, "care" is not a given, but a practice dependent on fluid social environments. They narratively navigated what care, or even explicitly "good" care, was. In these specific cases, they did so by subjunctively retaining ambivalence about which narrative best applies to the situation, creatively evoking cultural frameworks of understanding, and shifting back and forth between (apparently) contradicting narratives over time.

The intersubjectivity at the core of their navigations resonates with studies of caregiving practices that show how care workers and patients often work together, for example through "tinkering" (Mol, Moser, and Pols 2010; Yates-Doerr 2012), "improvisation" (Livingston 2012) and "moral experiments" (Mattingly 2014). Yet, the analysis of narrative navigation also brings into view how not all care is necessarily "good" care, at least not for all involved (cf. Stevenson 2014). In everyday practices of care in settings of profound social inequality and limited access to healthcare, it may be analytically impossible to neatly distinguish "care" from "neglect" (Pinto 2014, see also Garcia 2010). "The ethics of attending to the other" (Stevenson 2014:3) may result in experiences of good care and neglect, at the same time for different persons involved, or for the same individuals over time. Addressing how people narratively navigate care, therefore, illuminates the moral ambiguity of care that emerges in the intersubjective and temporal dynamics of the question of what good care is. ${ }^{2}$ Before moving to two examples of such narrative navigation of care, the following section contextualizes the setting in which these interactions took place and the study through which I came to be involved in these particular situations.

\section{HIV in Aceh, Indonesia}

Although AIDS at first spread slowly in Indonesia, the number of new infections has increased sharply in the first decade of the new millennium. ${ }^{3}$ Despite increased government attention to HIV care, support, and treatment since 2004, ART (antiretroviral treatment) adherence has remained low because of difficulties of drug supply and patient access (Butt 2011; Green and Nagar 2013). ${ }^{4}$ As in many other countries, people living with HIV in Indonesia keep experiencing stigma and discrimination, both in medical settings and in their everyday environments (Boellstorff 2013; Butt 2015; Hidayana and Tenni 2015). This situation of stigmatization and low ART adherence levels is reflected in the low-prevalence province of Aceh, which many Acehnese and other Indonesians alike consider to be

\footnotetext{
${ }^{2}$ While narrative is central to many healthcare interactions, it may not be prominent to all forms of caregiving. Routine practices of caregiving within families, for example, may take a rather different shape, as they may be much more "ritual" and "embodied" (Aulino 2016). People may express "care" in many different ways - which may not necessarily be conscious, or coherent (Taylor 2008).

3 Between 2005 and 2013 the incidence of HIV in Indonesia rose by 48\% (UNAIDS 2014).

4 A recent report by The Lancet and UNAIDS states that Indonesia is one of the six countries "facing the triple threat of high HIV burden, low treatment coverage, and no or little decrease in HIV infections" (UNAIDS-Lancet Commission 2015:175).
} 
the most Islamic part of Indonesia. Rapidly linking the arrival of AIDS to sexual immorality, many Acehnese consider AIDS a source of embarrassment for a province well known for its implementation of Islamic law (Samuels 2016a).

The first case of HIV in Aceh was detected only in 2004, months before the Indian Ocean tsunami destroyed large parts of the province. In the following year, a historic peace agreement brought an end to a violent separatist conflict that had haunted the area for three decades. After the disaster, the provincial hospital started to acquire expertise on HIV/AIDS and opened a Voluntary Counseling and Testing unit (VCT). As of June 2014, 272 people had been diagnosed throughout the province, the majority of them with AIDS. ${ }^{5}$ Healthcare facilities for people living with HIV remained mostly limited to the provincial hospital in Aceh's capital, Banda Aceh. People living with HIV whose status was voluntarily or, mostly, involuntarily disclosed, were known to experience severe discrimination in their villages, workplaces, families, local health clinics, and schools. Consequently, medical staff regularly counseled against disclosure.

Between August 2013 and July 2014, I conducted ethnographic research on HIV care in Aceh. I attended official meetings and awareness raising workshops that were organized by the government and the few organizations involved in the topic. Most of my time, however, was spent doing participant observation with a small patient support group in Banda Aceh, the only such group in the province. The support group was a non-governmental organization that had been established in 2006 and was linked to an umbrella organization in the Indonesian capital Jakarta. The four support group staff members received a monthly "incentive," a salary below minimum wage. They officially worked together with the provincial hospital on several fronts, for example in the organization of regular focused group discussions for members of the group. Support group staff helped members of the group to get the correct referral letters, visit the specialists in the right order, advocate in cases of discrimination, pick up medicines, and provide information as well as moral and emotional support.

I was particularly interested in the ways in which people affected by HIV dealt with such a major crisis in their lives in this piously Islamic and rapidly transforming society, bringing with me an analytic focus on narrative and the remaking of post-crisis everyday life that I developed in previous research on the Indian Ocean tsunami (see, e.g., Samuels 2016b). Over the course of my research, I conducted in-depth interviews with over thirty people living with HIV, and semistructured interviews with government officials, NGO-workers, and medical staff involved in HIV care and policymaking. Together with the support group staff I ensured that medical staff, patients and their family members were always informed about my research and agreed to my presence as a researcher. I mostly met with patients in the hospital, while following the support group in their daily work of accompanying them, or in the support group office, since for most people living

\footnotetext{
5 Data provided by the Provincial Health Office in Banda Aceh, June 2014. My personal conversations with support group staff in the past years suggest that usually up to ten new HIV diagnoses are made every month.
} 
with HIV, meeting with me outside of these spaces could increase the risk of disclosure. In this article, I have changed the names of my research interlocutors.

The Indonesian healthcare system that support group staff and patients dealt with on a daily basis has recently gone through major transformations as it is moving toward a system of universal health coverage. The province of Aceh, which in many ways occupies a special position because of its abundant natural resources and the far-reaching special autonomy position that separatist leaders negotiated in 2005, already had such a universal health coverage program since 2010. Although some observers have noticed the generosity of this program with respect to special cases - as reportedly it would even pay for patients to be brought to Jakarta for certain treatments (see Aspinall 2014:809)_the experiences of my interlocutors also point to the huge challenges for universal health coverage that remain in Aceh. These challenges reflect those that have been noted for Indonesia more broadly, including a complex referral system that forces people to travel long distances to obtain care, corruption in the medical education system and in acquiring government positions, a large absenteeism of medical staff and lacking stock of basic medicines in rural areas, the overburdening of district and provincial hospitals, a generally low level of quality of care, and a lack of accessibility for those without identity cards (Aspinall 2014; Harimurti et al. 2013; Nanwani and Siagian 2017; Pisani, Kok, and Nugroho 2017).

Despite the existence of insurance systems, if they had the means, almost all of my interlocutors and acquaintances in Aceh said they would rather visit the private practice of their preferred doctor or even go to Malaysia for treatment (see Smith 2015). Yet most of the people affected by HIV could not afford such expenses and therefore waited long hours in the public hospital, where, because of the rotation of specialists, they would see a different doctor on every visit. At the time of my research, medication and care for people living with HIV were already freely available for all. But since in Aceh almost all district hospitals professed not to be "ready" for treating HIV patients, patients had to travel to Banda Aceh to access care and treatment, which for some amounted to a bus-ride of up to seventeen hours. Fear of disclosure and discrimination often characterized this quest for care. For example, to prevent their local health practitioner from knowing of their affliction (which would risk disclosure in their villages), people living with HIV sometimes had to feign another illness to get a proper referral letter to the capital.

As in other places in Indonesia, hospitalization was a huge financial burden for many patients - since not only would they themselves not be able to work and take care of their families at home, they also needed to be accompanied by one or more family members who would take care of them in the hospital day and night, and who moreover would have to pay for their own meals and transportation. If they traveled to Banda Aceh and had to stay as out-patients to see different specialists and wait for tests and test results, there was the additional burden of finding a place to stay.

In the following stories, we will see how support group staff provide care on their own and together with medical staff. ${ }^{6}$ It is not only the patients who struggle to

\footnotetext{
${ }^{6}$ The Indonesian language has a range of words that could be translated as care- -though no one concept is as encompassing as the English language word. For example, the "caring about" that individuals or
} 
narratively navigate care-support staff, medical doctors and family members do so too, and often in various forms of interaction with each other. In the first vignette, concerning an emotionally demanding moment of diagnosis, it is the unexpected narrative creativity of a young woman that affects the practice of caring and offers a sense of commensurability in an "unfolding drama" (Mattingly 1998). In this situation, narrative navigation entails the appeal to a religious narrative that helps to keep the future open-ended rather than providing a clear plot.

\section{“God's Way is More Beautiful"}

On a Friday morning in June 2014, a family took an HIV test together. The father, Yunaldi, was seriously ill and had been diagnosed with AIDS a couple of days earlier. That morning, his wife Ira, and their college-age children, Eva, Rini and Azam, had a long counseling session with the VCT doctor, Doctor Yani. After the session, support group staff member Rahma and I walked with the four of them from the VCT to the lab at the other side of the hospital. At first, Eva and Rini were cheerfully chattering with me about their university education, but as we approached the lab, Eva nervously said that she was afraid. "So, what would you do if you would test positive?" Rahma asked her, and Eva promptly answered that she would kill herself. Rahma retorted it was not allowed to do that, implicitly referring to the Islamic doctrine that forbids suicide.

In the afternoon, the results were ready. Rahma and I picked up four sealed envelopes at the lab and returned to the VCT, where Mrs. Ira and Doctor Yani were waiting for us. We sat down in the small counseling room: Doctor Yani behind her desk, Mrs. Ira in front of it and Rahma next to her. I leaned on the bed behind them. What follows is an excerpt from the field notes that I wrote immediately after this conversation:

Doctor Yani Whatever the result may be, you will accept it, right?

Mrs. Ira Yes.

Doctor Yani Shall we open the envelopes of the children?

Mrs. Ira Yes.

Doctor Yani opens the envelopes and silently reads the results. She appears stoic, but I have the impression that things are not right. She puts the forms back in.

Footnote 6 continued

bureaucracies might do (or refrain from) is often indicated by the terms peduli ("concern") or perhatian ("attention"). Intensive physical care in the hospital or at home is usually called perawatan. The way in which relatives care for someone in the hospital (including bathing and feeding) is called menjaga or mengurus ("to look after"). Support group workers characterized what they did as dukungan (support) and pendampingan (accompaniment). 
Doctor Yani The children first, right?

She opens the envelopes again one by one. All three times Rahma looks at the forms and whispers Alhamdulillah, thank God. Doctor Yani points at the results and reads out loud: "Eva non-reaktif, Rini non-reaktif, Azam non-reaktif."

Mrs. Ira says she is hugely relieved: "The children are the most important." Rahma concurs by saying that they indeed "still have the longest breath" [i.e. they are still young]. Then Mrs. Ira asks, knowingly, "but I am positive, right?" Rahma answers with another question: "If you are positive, will you be willing to take medication?" Mrs. Ira nods and Doctor Yani gives her her form, pointing at the result: reaktif. Mrs. Ira responds only by saying that her children should not know about this result. They will be here any moment. The three of them agree that they won't tell the children.

Three people carefully navigated through a highly sensitive moment of diagnosis together. In another context, Rahma's question "will you be willing to take medication?" could perhaps be interpreted as controlling, disciplining, ensuring that the patient will start taking antiretroviral drugs (cf. Mattes 2011). Here, however, it seemed to mainly do something else: right before Mrs. Ira heard that she was HIVpositive, Rahma tried to soften the blow by assuring her that there was medication to help her. Doctor Yani, meanwhile, sensed correctly that the children were what counted most to Mrs. Ira and, perhaps against official rules of disclosure, told her the good news about her children first. Mrs. Ira knew why Doctor Yani was giving her these good results first, but nevertheless seemed glad to have positive news to hold on to. In the ethical space of this interaction, following the rules was not what counted most. Instead, care unfolded creatively, as all three women were doing their best to make the situation as bearable as possible. The need for improvisation became even more clear when Mrs. Ira's daughters entered the room:

Doctor Yani immediately tells them that they have tested negative and shows them their forms. For one moment they are happy, but then Eva asks to see their mother's form. Mrs. Ira tries to act casually: "It is not there." But her daughters do not believe her and Doctor Yani has to interrupt by saying that their mother has to take another test on Monday. This doesn't sound convincing either and Rini and Eva know enough and start to cry. Doctor Yani mutters that they really should not tell their brother, whom they know will be extremely angry with their father.

Rahma tries to comfort Eva, who cries unstoppably, by saying: "Don't cry, your mother will be sad because of it, you have to help her think positively. Accept this, your mother will take medication and will be there for a long time, like the man you met yesterday [a support group member]; he has been taking medicines for fourteen years already!" And when this does not help much: "Don't hate your father, please give support to your mother." Eva cries that her mother will die, but Rahma retorts that there are medicines that will help her. "But mother looks so healthy...," Rini, who has her head on my 
shoulder, whispers quietly. Eva keeps crying loudly and Rahma and Doctor Yani seem to be at a loss.

Then, suddenly, Rini sits upright, wipes her tears away and says: "Whatever the story is, God's way is more beautiful." (apapun cerita, jalan Tuhan lebih indah). Eva calms down and Rahma and Doctor Yani nod gratefully. "How did you put it again?" Rahma asks, and, more confidently now, Rini says: "Whatever the story is, God's plan is more beautiful." (rencana Tuhan lebih indah). Rahma and Doctor Yani repeat this and pick up her religious invocation that implies acceptance of fate as well as the possibility of good things to come and all seem relieved. Rahma hugs Eva and Rini hugs her mother, after which the daughters ask Doctor Yani about medication and the doctor gives advice on nutrition. The session ends without Azam having arrived yet and after we say goodbye, the family walks back to the care ward where Yunaldi is.

I have drawn at length on this particular interaction to reveal how in the practice of HIV care, patients, doctors, support workers and others may together stumble through a difficult situation, trying to create a narrative that gives all involved a more positive image of the future. Whereas Rahma's emphasis on positive thinking does not help to engage Eva into imagining a more positive future, Rini's spontaneous religious invocation does. Suddenly, the overwhelming diagnosis becomes a moment in an unfolding drama: While there may be no way to know what the future will bring, Rini's caring words reinforce the religious trust that somehow there will be something "more beautiful" in this story.

From within the situation, Rini appeals to a shared cultural framework that is, as Linda Garro (2005:63) has put it, a means "for navigating the ambiguity surrounding illness and other troubling experiences." While in Garro's study cultural frameworks help to give meaning to experience, I would say that in this case Rini's appeal to the open-endedness of the better future that is invariably in God's hands, is not just a way to make sense of what happens to them but also an act of care. It is by evoking religious trust in the face of uncertainty about the future, indeed trust in "whatever the story is," that Rini gives hope to all involved. The effect of her appeal to this new narrative is an immediate mood change-from despair to relief, a change that all of us responded to, revealing the intermediary and transitional qualities of moods (Throop 2014). More successfully than Rahma and Doctor Yani, Rini does "emotion work," answering the call to manage the feelings of Eva, her mother and herself (Wikan 1989). Doctor Yani and Rahma gratefully draw Rini's suggestion into their narrative by having her repeat it and repeating it themselves and as the mood changes, they manage to expand to their other, better rehearsed, ways of caring that include advice on nutrition, medicine and positive thinking.

Here, narrative navigation enabled all to "keep going" (Zigon 2012), to move forward from a moment of despair, making poignantly clear how stories emerge in "fields of intersubjectivity" rather than being "pure creations of individuals" (Jackson 2013[2002]:40). Importantly, in this process of navigation, Rini did not offer a plotted trajectory for the future. Unlike the doctor and support group staff 
member, who invoked a plot of staying healthy through medication and positive thinking, successful navigation here meant to not create a new plot, but leaving open how the story would or could proceed. If narrative helps to renew "faith that the world is within our grasp" (Jackson 2013[2002]:36), here it did so exactly through the acceptance of the human impossibility to control the world-through the deeply ingrained cultural sensibility that whatever happens is part of God's plan and is by nature full of divine wisdom. As I have suggested elsewhere in drawing on the life story of an HIV-positive woman who struggled to retain a range of seemingly incompatible values and hopes, the subjunctive mode of narrative may enable people to move on, exactly by leaving the future open (Samuels 2018). Narrative "haziness," Cheryl Mattingly (2014:123) points out, may be cultivated "not in order to avoid seeing what is ahead, but in order to face it." In the story of Mrs. Ira's diagnosis we see how cultivating such a hazy, under-plotted, future may be a crucial facet of the narrative navigation of care.

The actors involved navigate what care should be and how they may care for each other. For example, one might read the disclosure of the mother's positive status to her children (and, perhaps, the disclosure of the children's negative status to the mother) as an act of either care or neglect, the extension of help or the trampling of human rights. Yet, I am reluctant to judge disclosure here as falling into either of these categories. Instead, the interaction quoted above shows that disclosure was not a neatly bounded "act" at all. It was the document's absence, rather than anything that Doctor Yani or Rahma said, which disclosed Mrs. Ira's status to her daughters. Eva and Rini could not be fooled by the lie that Mrs. Ira had to take another test: Even without seeing the form or hearing a confirmation, they were convinced of the diagnosis. Disclosure, then, may happen through silence and absence, as much as through what is actually said. ${ }^{7}$

Of course, other scenarios might have been possible. Indeed, the doctor could have decided to give the results to Mrs. Ira, Eva and Rini individually, without the others being present-but this may not have relieved Mrs. Ira from her daughters' inquiries about the form later on. In that case, there would have been no-one else to help her console her daughters and it is therefore quite uncertain that an individual approach would necessarily have resulted in better care from the perspective of the patient and her daughters. What is care and what is violation here cannot easily be determined. As Sarah Pinto (2014:252) notes in her insightful work on women and mental health in northern India, "[t]he vitally important work of finding a way through a life with others, and of illness and healing, happened at points at which freedom and abandonment, or care and confinement were not easily distinguished." Similarly, the unfolding of the particular situation of Ibu Ira's diagnosis illustrates how narrative and silent processes of disclosure trouble the boundaries between care and neglect, and preclude from an easy moral judgement on upholding or violating the patient's right to secrecy.

People do not always manage to agree on common narratives of care in the way the change of mood after Rini's religious appeal suggested. The next story figures a

\footnotetext{
7 Indeed, ethnographic studies show that silence and disclosure of HIV do not necessarily contradict each other (e.g., Black 2015; Moyer 2012).
} 
painful interaction in which narratives of care remain incommensurable. It starts in the same hospital where Mrs. Ira received her diagnosis, but here I follow not only Rahma but also Nila, a support worker in her mid-thirties who had started working for the group in 2007. A dedicated activist, care worker and mother of two, Nila took great effort to juggle the long days of care for the group's members with care for her own family. In the following interaction, she adamantly disagrees with a severely ill patient about his decision to leave the hospital. Yet, not only does she allow room for alternative narratives of care within the situation, over time she adjusts her perspective, allowing the narrative of what good care is to move within the moving parts that shape its possibilities.

\section{Going Home}

It was a hectic day in December 2013. Nila, Rahma and I had been accompanying several patients already when we met Intan, a young woman who would over time become an active member of the support group. Intan immediately and hurriedly asked us to accompany her. Her husband was severely ill and had been admitted to one of the care wards two weeks earlier. Both of them had recently been diagnosed with HIV, and since Intan thought she might be pregnant, she wanted to see a gynecologist as soon as possible. Nila and I went with her to the gynecology polyclinic, but it was only the next day that we, together with Rahma, managed to visit Intan's husband Abdullah in his one-patient room in the care ward. The scene that unfolded there was disquieting to me. It revealed how narratives of care may be incommensurable, and, again, how care and neglect may simultaneously shape a healthcare interaction without being easy to distinguish or name. However, it also revealed how people navigated such incommensurable narratives. I made the following notes:

Abdullah is lying on the bed. He is very thin and his neck is swollen because of his tuberculosis. Intan seems nervous. Nila tells Abdullah in Acehnese what the doctor had already told him before; that he should stay in the hospital, where they will treat his liver condition and tuberculosis and then he can start with ART, but he refuses, continuously repeating that he wants to go home (Ac. jak woe). Nila rubs his back and he starts to cry, upon which Rahma cheerfully says: "Come on, men should not cry!" Intan, Rahma and Nila start laughing and they continue doing so when Abdullah cries out that he will jump from the third floor balcony if they don't let him go, saying that he wants to kill himself. "You can't," says Nila, "your wife is pregnant." The women keep laughing, but Abdullah doesn't join, looking extremely distressed.

Nila keeps repeating that he needs medication and Abdullah suddenly asserts in Indonesian that she doesn't care for him (tidak sayang sama saya). Nila starts a long reply in Acehnese and Indonesian, arguing that if he goes home now, that would mean he doesn't care for himself (tidak sayang sama diri sendiri). She pulls in other arguments, referring to others who survived tuberculosis when they started ART, and saying that if Abdullah's liver 
condition deteriorates further he might need expensive medication that would not be covered by the health insurance program. As he keeps crying that he wants to go home, she tries to convince him to at least not go to traditional healers. Stepping outside of the room with Intan and me, Nila says that given his psychological state perhaps indeed he had better go home. Back inside the room she tries to convince him again to stay and then warns that the decision is his own responsibility (tanggung jawab) and that he should not blame the hospital later. Indeed, the doctor makes an exit letter for him, which he will have to sign to relieve the institution from the responsibility of sending him home.

The laughter in the face of Abdullah's crying confused me. Could this possibly be part of "caring"? Laughter, Julie Livingston (2012:51) argues, is often a spontaneous response to pain and may be "a social experience for reinstating and reestablishing community in moments of terrible anxiety and duress." I had often seen Nila and Rahma lightheartedly joking with patients, effecting-not unlike Rini's religious interjection - a mood change that would help to subsequently create a more positive outlook on the future. Within the support group, people indeed often felt relieved by joking and making light of the situation. At times, they theorized laughter as part of positive thinking and thereby a way to foster health (cf. Wikan 1989:300). But Abdullah's intense distress did not allow for this uplifting change of mood; his suicidal threats were real. Neither the laughter nor Nila's gentle rubbing of his back pulled him into the constructive conversation that Nila and Rahma were hoping for. Instead, considering prevailing patriarchal gender relations and notions of masculinity in Aceh, the laughter of the healthy women standing beside the bed on which Abdullah could just lie down must have been embarrassing for him.

Nila resorted to a range of moral and medical arguments to convince Abdullah to stay in the hospital. She argued with Abdullah about what good care would be in a discussion in which Abdullah invoked the Indonesian word sayang, commonly translated as "love" or "affection," but in this situation also indexing a form of "caring about" oneself or another person. Out of earshot, however, Nila was more ambivalent, suggesting that perhaps he should indeed go home. She thereby used what Shohet (2017), following Ochs and Capps (2001), has called "sideshadowing narratives": narratives that articulate the indeterminacies of everyday life instead of providing unavoidable trajectories of pasts and futures. Shohet (2017:556-557) argues that, rather than in straightforward, linear stories that focus on hindsight ("backshadowing narratives") or sketch a future trajectory as inevitable ("foreshadowing narratives"), sideshadowing narratives allow people to "embrace contradictory positions." By allowing for inconsistency, sideshadowing fosters the open-endedness that is often essential for moving through precarious situations. Inside the hospital room, Nila's narrative of care at first seems not to allow for the possibility that Abdullah should go home; and yet she relents a bit by mentioning that if he does, he should not resort to traditional medicine (meaning that he should not stop using the drugs provided by the medical doctors). Outside of the room, her sideshadowing narrative goes further and allows for the contradictory position that it might actually be even better for him to leave the hospital. 
During the interaction, Intan had mostly kept to the side, though clearly sharing in the laughter and supporting the arguments for Abdullah to stay. However, in a private interview that I had with her a few months later, she told me that at the time she already knew that Nila's efforts would be useless. She herself had tried to convince her husband to stay in the hospital by arguing that seeking medical treatment is a religious obligation-referring to the Islamic notion that it is mandatory to take care of oneself. But prior to our visit that morning he had made up his mind, telling her that he refused to wait until the day that he would go home "as a dead body."

Five days after Abdullah and Intan went home to their village, we received the sad news that Abdullah had passed away. I was struck by Nila's response, as she said that he probably would not have survived in the hospital either-suggesting that his quick death meant that medication would have come too late anyway. Intan later told me that perhaps he had insisted on going home because he had already sensed that death was coming. The retrospective statements of both Nila and Intan made sense not only in light of Abdullah's last days, but also against the background of the Islamic notion of death as fated. From this perspective, no-one can know in advance what miracles may happen either at home or in the hospital, but the person who is going to die may-at a different level of consciousness-sense death approaching.

After Abdullah's death, both Nila's and Intan's narrative of what would have been good care changed remarkably, as both of them implicitly recognized that by making his decision Abdullah had indeed cared for himself - though in a way that differed from dominant notions of responsible medical care. Instead, he had made sure that his last wish, of dying at home rather than in the hospital, had been fulfilled. ${ }^{8}$ Over time, Nila and Intan framed both options, of going home and staying in the hospital, as caring and not caring. In their longer-term narrative navigation of care for Abdullah, Nila and Intan both engaged in a process of "narrative reenvisioning" (Mattingly 2014), adjusting their stories as they navigated the uncertainty of how to proceed and what story to tell-to Abdullah, themselves, each other, and me.

Nila and Intan's work of sideshadowing and narrative re-envisioning in the face of the intense distress of the situation in the hospital and the tragedy of Abdullah's death, reveals how narrative navigation is a tenuous and always incomplete process, a struggle to figure out what stories to tell and retell within a changing narrative. It also shows the flexibility and multiplicity of modes of HIV-care within ongoing relationships. Indeed, whereas studies of HIV-care in clinical settings have sometimes emphasized one dominant mode of caregiving by medical staff, such as disciplining (e.g., Beckmann 2013; Mattes 2011), or empowering (e.g. Robins 2006, Russell et al. 2016), a long-term perspective on the relations between care workers and patients may show a more diverse pattern, complicating notions of care as a unified practice (see, e.g., Maes 2014; Moyer 2014; Prince 2012; Whyte,

\footnotetext{
8 Anthropologists have pointed out that dying at home instead of in the hospital may be spiritually significant in Southeast Asian societies (see, e.g., Desjarlais 2016; Shohet 2018a; Stonington 2012). Although it is unsure to what extent spiritual considerations informed Abdullah's wish to die at home, clearly the location of death mattered greatly to him.
} 
Whyte, and Kyaddondo 2010). Addressing how people narratively navigate care helps to bring out this nuance, illuminating the contradictory or complementary modes of care that people engage in over time, or hold on to simultaneously.

\section{Conclusion}

The two ethnographic vignettes above show how HIV-patients, family members, support workers and medical staff narratively navigate what care is, should be, or could have been. It is a process of incomplete emplotment that helps them figure out how to act and feel, and how to move within moving social forces (cf. Vigh 2009). In the unfolding of their relationships of care, stories may be multiple and changeable in the telling and in the retelling that happens later (cf. Mattingly 2010).

The stories from Aceh show that narrative navigation of care requires continuous adjustment to new circumstances. While sometimes this becomes poignantly clear within the timeframe of one particular interaction-such as in Mrs. Ira's diagnosis - it is often a long-term perspective that reveals how in caregiving and care-receiving, people show ambivalence about the possibilities of care, shift back and forth between multiple narratives of good care, and retain a range of possible future trajectories. In the face of profound uncertainty, sustaining multiple narrative possibilities may help to prepare oneself for a future with HIV (cf. Whyte 2002).

Actively maintaining "subjunctivizing elements" (Good 1994:153) may include thinking through more or less clearly plotted trajectories for the future-as when Nila spells out for Abdullah what medical steps need to be taken in the hospital before he can start ART, and what may happen when he goes home, including the financial burden he could become to his family. It may also include sideshadowing, and keeping less plotted futures within the realm of possibility. For Eva, what helped most in a moment of agony was not the rather clear-cut optimistic narrative that depicted her mother taking medication and becoming as healthy as the exemplary support group member. Instead, it was her sister's appeal to an as yet uncertain, but divinely determined future that helped her to accept the situation, "whatever the story is." Subjunctivizing elements, and particularly the non- or under-plotted futures they enable, are therefore key narrative devices in the navigation of care.

The HIV-care interactions recounted in this article exemplify a general process of narratively navigating care that I encountered in Aceh, when following caregivers and patients throughout their recurrent hospital visits. A lot was at stake in the crafting and adjusting of narratives of care, since narrative itself could bring certain possibilities of care into being, and foreclose others. As Merav Shohet (2018b:508) puts it, "narrative genres ... actually propel health-relevant states of being, by enlivening and creating these realities in the process of telling." Taking narrative navigation as an analytical lens to study illness and care, then, reveals the complex and contradictory process of caregiving and receiving, in which the same practices may be variously, and even simultaneously, experienced as caring and not-caring. 
Acknowledgements This study was funded by the Netherlands Organisation for Scientific Research (NWO) and the Marie Skłodowska-Curie Actions. Previous versions of this article have been presented at the University of Connecticut, the University of Michigan-Flint, and the 2017 Biennial Meetings of the Society of Psychological Anthropology in New Orleans. I thank the audiences of these talks for their questions, and Merav Shohet, Sylvia Tidey, Saiba Varma, Daniel Birchok, Samuel Martínez, César Abadía-Barrero, as well as two anonymous reviewers of Culture, Medicine and Psychiatry for their helpful suggestions. My deepest gratitude goes to my interlocutors in Aceh.

\section{Compliance with Ethical Standards}

Conflict of interest The author, Annemarie Samuels, declares that she has no conflict of interest.

Ethical Approval All procedures performed in studies involving human participants were in accordance with the ethical standards of the institutional and/or national research committee and with the 1964 Helsinki declaration and its later amendments or comparable ethical standards.

Informed Consent Informed consent was obtained from all individual participants included in the study.

Open Access This article is distributed under the terms of the Creative Commons Attribution 4.0 International License (http://creativecommons.org/licenses/by/4.0/), which permits unrestricted use, distribution, and reproduction in any medium, provided you give appropriate credit to the original author(s) and the source, provide a link to the Creative Commons license, and indicate if changes were made.

\section{References}

Abadía-Barrero, César E.

2011 "I have AIDS but I am Happy": Children's Subjectivities, AIDS, and Social Responses in Brazil. Bogotá: Universidad Nacional de Colombia.

Aspinall, Edward

2014 Health Care and Democratization in Indonesia. Democratization 21(5):803-823.

Aulino, Felicity

2016 Rituals of Care for the Elderly in Northern Thailand: Merit, Morality, and the Everyday of Longterm Care. American Ethnologist 43(1):91-102.

Beckmann, Nadine

2013 Responding to Medical Crisis: AIDS Treatment, Responsibilisation and the Logic of Choice. Anthropology \& Medicine 20:160-174.

Boellstorff, Tom

2013 Person with HIV/AIDS (Orang Dengan HIV/AIDS). In Figures of Southeast Asian Modernity. Joshua Barker, Erik Harms, and Johan Lindquist, eds., pp. 141-143. Honolulu: University of Hawai'i Press.

Black, Steven P.

2015 The Morality of Performance: HIV Disclosure in Speech and Song in South Africa. Ethos 43(3):247-266.

Butt, Leslie

2011 Can you Keep a Secret? Pretenses of Confidentiality in HIV/AIDS Counseling and Treatment in Eastern Indonesia. Medical Anthropology 30:319-338.

2015 Sexual Tensions: HIV-Positive Women in Papua. In Sex and Sexualities in Contemporary Indonesia: Sexual Politics, Health, Diversity and Representations. Linda Rae Bennett and Sharyn Graham Davies, eds., pp. 109-128. London: Routledge.

Desjarlais, Robert

2016 Subject to Death: Life and Loss in a Buddhist World. Chicago: The University of Chicago Press. 
Garcia, Angela

2010 The Pastoral Clinic: Addiction and Dispossession along the Rio Grande. Berkeley: University of California Press.

Garro, Linda C.

2005 "Effort after Meaning" in Everyday Life. In A Companion to Psychological Anthropology: Modernity and Psychocultural Change. Conerly Casey and Robert B. Edgerton, eds., pp. 48-71. Oxford: Blackwell.

2003 Narrating Troubling Experiences. Transcultural Psychiatry 40(1):5-43.

Good, Byron J.

1994 Medicine, Rationality, and Experience: An Anthropological Perspective. Cambridge: Cambridge University Press.

Good, Byron J., and Mary-Jo DelVecchio Good

2000 "Fiction" and "Historicity" in Doctors' Stories: Social and Narrative Dimensions of Learning Medicine. In Narrative and the Construction of Illness and Healing. Cheryl Mattingly and Linda C. Garro, eds., pp. 50-69. Berkeley: University of California Press.

1994 In the Subjunctive Mode: Epilepsy Narratives in Turkey. Social Science \& Medicine 38(6):835842.

Green, Chris W., and Katherine Nagar 2013 Care, Support \& Treatment for PLHIV in Indonesia. http:// spiritia.or.id/art/bacaart.php?artno=2018. Accessed 16 Jan 2017.

Harimurti, Pandu, Eko Pambudi, Anna Pigazzini, and Ajay Tandon 2013 The Nuts and Bolts of Jamkesmas: Indonesia's Government-Financed Health Coverage Program. Universal Health Coverage Studies Series (UNICO) No. 8. Washington, DC: The World Bank.

Hidayana, Irwan M., and Brigitte Tenni

2015 Negotiating Risk: Indonesian Couples Navigating Marital Relationships, Reproduction and HIV. In Sex and Sexualities in Contemporary Indonesia: Sexual Politics, Health, Diversity and Representations. Linda Rae Bennett and Sharyn Graham Davies, eds., pp. 91-108. London: Routledge.

Hutchins, Edwin

1995 Cognition in the Wild. Cambridge, MA: MIT Press.

Jackson, Michael

2013[2002] The Politics of Storytelling: Variations on a Theme by Hannah Arendt [second edition]. Copenhagen: Museum Tusculanum Press.

Kleinman, Arthur

1988 The Illness Narratives: Suffering, Healing, and the Human Condition. New York: Basic Books. Livingston, Julie

2012 Improvising Medicine: An African Oncology Ward in an Emerging Cancer Epidemic. Durham: Duke University Press.

Maes, Kenneth

2014 "Volunteers are not Paid because they are Priceless": Community Health Worker Capacities and Values in an AIDS Treatment Intervention in Urban Ethiopia. Medical Anthropological Quarterly 29:97-115.

Mattes, Dominik

2011 "We are just Supposed to be Quiet": The Production of Adherence to Antiretroviral Treatment in Urban Tanzania. Medical Anthropology 30:158-182.

Mattingly, Cheryl

2014 Moral Laboratories: Family Peril and the Struggle for a Good Life. Berkeley: University of California Press.

2010 The Paradox of Hope: Journeys through a Clinical Borderland. Berkeley: University of California Press.

1998 Healing Dramas and Clinical Plots: The Narrative Structure of Experience. Cambridge: Cambridge University Press.

Mattingly, Cheryl, and Linda C. Garro, eds.

2000 Narrative and the Construction of Illness and Healing. Berkeley: University of California Press.

Mol, Annemarie, Ingunn Moser, and Jeanette Pols

2010 Care: Putting Practice into Theory. In Care in Practice: On Tinkering in Clinics, Homes and Farms. Annemarie Mol, Ingunn Moser, and Jeanette Pols, eds., pp. 7-25. Bielefeld: Transcript Verlag. 
Moyer, Eileen

2014 Peer Mentors, Mobile Phone and Pills: Collective Monitoring and Adherence in Kenyatta National Hospital's HIV Treatment Programme. Antropology \& Medicine 21:149-161.

2012 Faidha Gani? What is the Point: HIV and the Logics of Non-Disclosure among Young Activists in Zanzibar. Culture, Health and Sexuality 14(S1):S67-S79.

Nanwani, Sandeep, and Clara Siagian

2017 Falling through the Cracks. Inside Indonesia http://www.insideindonesia.org/falling-through-thecracks. Accessed 8 Aug 2018.

Ochs, Elinor, and Lisa Capps

2001 Living Narrative: Creating Lives in Everyday Storytelling. Cambridge, MA: Harvard University Press.

Pinto, Sarah

2014 Daughters of Parvati: Women and Madness in Contemporary India. Philadelphia: University of Pennsylvania Press.

Pisani, Elizabeth, Maarten O. Kok, and Kharisma Nugroho

2017 Indonesia's Road to Universal Health Coverage: A Political Journey. Health Policy and Planning 32(2):267-276.

Prince, Ruth

2012 HIV and the Moral Economy of Survival in an East African City. Medical Anthropological Quarterly 26:534-556.

Robins, Steven

2006 From "Rights" to "Ritual": AIDS Activism in South Africa. American Anthropologist 118:312323.

Russell, Steve, Stella Namukwaya, Flavia Zalwango, and Janet Seeley

2016 The Framing and Fashioning of Therapeutic Citizenship among People Living with HIV Taking Antiretroviral Therapy in Uganda. Qualitative Health Research 26:1447-1458.

Samuels, Annemarie

2018 "This Path is Full of Thorns": Narrative, Subjunctivity, and HIV in Indonesia. Ethos 46(1):95-114.

2016a Seeing AIDS in Aceh: Sexual Moralities and the Politics of (In)visibility in Post-Reconstruction Times. Indonesia 101:103-120.

2016b Embodied Narratives of Disaster: The Expression of Bodily Experience in Aceh, Indonesia. Journal of the Royal Anthropological Institute (N.S.) 22:809-825.

Shohet, Merav

2018a Two Deaths and a Funeral: Ritual Inscriptions' Affordances for Mourning and Moral Personhood in Vietnam. American Ethnologist 45:60-73.

2018b Beyond the Clinic: Eluding a Medical Diagnosis of Anorexia through Narrative. Transcultural Psychiatry 55(4):495-515.

2017 Troubling Love: Gender, Class, and Sideshadowing the "Happy Family" in Vietnam. Ethos 45(4):555-576.

2007 Narrating Anorexia: "Full" and "Struggling" Genres of Recovery. Ethos 35:344-382.

Smith, Catherine

2015 Doctors that Harm, Doctors that Heal: Reimagining Medicine in Post-Conflict Aceh, Indonesia. Ethnos 80(2):272-291.

Stevenson, Lisa

2014 Life Beside Itself: Imagining Care in the Canadian Arctic. Berkeley: University of California Press.

Stonington, Scott

2012 On Ethical Locations: The Good Death in Thailand, where Ethics sits in Places. Social Science and Medicine 75:836-844.

Taylor, Janelle

2008 On Recognition, Caring, and Dementia. Medical Anthropology Quarterly 22(4):313-335.

Throop, C. Jason

2014 Moral Moods. Ethos 42:65-83.

UNAIDS

2014 The GAP Report. Geneva: Joint United Nations Programme on HIV/AIDS.

UNAIDS-Lancet Commission

2015 Defeating AIDS-Advancing Global Health. The Lancet 386:171-218. 
Vigh, Henrik

2006 Navigating Terrains of War: Youth and Soldiering in Guinea-Bissau. Oxford: Berghahn.

2009 Motion Squared: A Second Look at the Concept of Social Navigation. Anthropological Theory 9(4):419-438.

Whyte, Susan R.

2002 Subjectivity and Subjunctivity: Hoping for Health in Eastern Uganda. In Postcolonial Subjectivities in Africa. Richard Werbner, ed., pp. 171-190. London: Zed Books.

Whyte, Susan R., Michael A. Whyte, and David Kyaddondo

2010 Health Workers Entangled: Confidentiality and Certification. In Morality, Hope and Grief: Anthropologies of AIDS in Africa. H. Dilger and U. Luig, eds., pp. 80-101. New York: Berghahn.

Yates-Doerr, Emily

2012 The Weight of the Self: Care and Compassion in Guatemalan Dietary Choices. Medical Anthropological Quarterly 26:136-158.

Wikan, Unni

1989 Managing the Heart to Brighten Face and Soul: Emotions in Balinese Morality and Health Care. American Ethnologist 16:295-312.

Zigon, Jarrett

2012 Narratives. In A Companion to Moral Anthropology. Didier Fassin, ed., pp. 204-220. Malden, MA: Wiley-Blackwell. 